\title{
Genetic Polymorphism of Cytokines as a Predictor of Phenotypic Development of Chronic Pain Syndrome in Cancer Patients
}

\author{
Olga P. Bobrova, $\mathrm{PhD}^{1,2}$; Natalia A. Shnayder, $\mathrm{PhD}, \mathrm{ScD}^{* 1}$; \\ Marina M. Petrova, $\mathrm{PhD}, \mathrm{ScD}^{1}$; Oksana A. Gavrilyuk, $\mathrm{PhD}^{1}$ \\ ${ }^{I}$ V. F. Voyno-Yasenetsky Krasnoyarsk State Medical University \\ ${ }^{2}$ Krasnoyarsk Regional Clinical Oncology Dispensary named after A.I. Kryzhanovsky \\ Krasnoyarsk, the Russian Federation
}

\begin{abstract}
The authors present a literature review using materials provided in the following databases: "MedLine", "PubMed", "Wiley Online Library", "Web of Science", "Oxford University Press", "SAGE Premier", dated 1995-2016. The paper describes the results of current international studies on the role of cytokine genes polymorphisms in the genesis of chronic cancer pain. We emphasize the role of inter-individual differences based on genetic polymorphism of cytokines and their receptors in personalized anesthetic care and accompanying therapy in oncology. (International Journal of Biomedicine. 2017;7(4):277-281.)
\end{abstract}

Key Words: chronic pain $\bullet$ oncology $\bullet$ analgesic therapy $\bullet$ pharmacogenetics $\bullet$ nociception $\bullet$ cytokine receptors

\section{Abbreviations}

CB2, cannabinoid receptor 2; CX3CL1, chemokine (C-X3-C motif) ligand-1; CXCR3, CXC chemokine receptor 3; CCL, CC chemokine ligand; COX-2, cyclooxygenase 2; ERK-kinase, extracellular signal-regulated kinase; IL, interleukin; IFN- $\gamma$, interferon gamma; MCP-1, monocytic chemotactic protein-1; NGF, nerve growth factor; NOS3, nitric oxide synthase 3; PG, prostaglandin; SNPs, single nucleotide polymorphisms. TGF, transforming growth factor, XC, XC chemokines.

\section{Introduction}

A high prevalence of chronic pain syndrome in oncological patients represents a challenging issue of palliative care. The influence of different factors on chronic pain progress and drug resistance to analgesic therapy is associated with an understanding of the complex pathogenic mechanisms of this pain. ${ }^{(1)}$ Mechanical damage to peripheral neurons by cancer cells activates a cascade of pathophysiological processes in the nociceptive system. Cancer cells are also known to produce algogenes. ${ }^{(2)}$ Nociceptive receptors are excited in response to

*Corresponding author: Prof. Natalia A. Shnayder, PhD, ScD; Head of the Neurological Center of Epileptology, Neurogenetics and Brain Research of the University Clinic of V.F. Voino-Yasenetsky Krasnoyarsk State Medical University. Krasnoyarsk, the Russian Federation. E-mail: nataliashnayder@gmail.com inflammatory and tumor-induced algogenes, which leads to an increase in pain syndrome severity. ${ }^{(3)}$ Prostaglandins and a number of biologically active substances (endothelin, TNF $\alpha$, IL-1, IL-6, EGF, PDGF, extracellular hydrogen ions H+, ET-1) ensure primary sensitization of nociceptors. ${ }^{(4,5)}$ Moreover, cancer cell activity causes a metabolic acidosis that impairs sensory neurons. Therefore, excitation of nociceptive receptors is influenced by both mechanical and proinflammatory factors. Proteolytic damage to nociceptors predetermines the genesis of inflammatory cancer pain and the progression of cancer. ${ }^{(6)}$

Immune competent cells, glial cells and cancer cells produce damaged cytokines. ${ }^{(7,8)}$ Proinflammatory cytokines (TNF- $\alpha$, IL-1, IFN- $\gamma$, and IL-6) and anti-inflammatory cytokines (IL-10, IL-4, and TNF- $\beta$ ) are known as markers of tissue damage. ${ }^{(9)}$ IFN- $\gamma$ is a key modulator of CB2 receptors. ${ }^{(7)}$ Activation of $\mathrm{CB} 2$ receptors located in glial cells contributes to neuropathic pain. Cytokines might participate 
in the proliferation and angiogenesis of cancer cells. ${ }^{(9)} \mathrm{IL}-1 \beta$, TNF- $\alpha$ and IL- 6 are early cytokines synthesized in response to neuron damage and are potent COX-2 activators. ${ }^{(10)} \mathrm{COX}$ 2 upregulation leads to tissue alteration and an increase in neuron sensitization. ${ }^{(7,11)}$ In cases of cancer pain, cytokines promote pain sensitivity through direct cellular interaction or nociceptor activity modulation. ${ }^{(1,9)} \mathrm{A}$ total of 50 known cytokine ligands ensure their interaction with different cells of the organism. Ligands are conditionally subdivided into CCL, CXC, CX3C, and XC. ${ }^{(12,13)}$ Cytokine receptors are widely represented in leukocytes, neurons and glial cells. ${ }^{(14)}$ However, ligands are not strictly specific and might mediate pain signals through interaction with many types of receptors. ${ }^{(15)}$

Therefore, cytokine regulation of receptors and ion channels accounts for nociceptive and neuropathic pain components. ${ }^{(12,16)}$ The main mechanism serving as the basis for development of neuropathic and nociceptive pain components is MCP-1 cytokine induction. MCP-1 only acts through CCR2 receptors and ensures the neuropathic pain mechanism. The CX3CL1 chemokine participates in the pathophysiology of neuropathic pain by induction of IL-1 and IL-6. The cytokine IL-1 $\beta$ participates in the genesis of neuropathic pain. ${ }^{(17)}$ CXCR3 is of critical importance in the development of bone cancer pain through Akt-kinase and intracellular ERK-kinase signaling pathways. ${ }^{(18)}$ The known spliced variants of CXCR3 may account for phenotypic variations, but it is a subject of discussion at the present day. ${ }^{(18)}$

The purpose of this study was to explore the results of pharmacogenetic research on the association between cytokine gene polymorphism and chronic pain syndrome in oncological patients.

\section{Materials and Methods}

We have analyzed recent full-text publications in such international databases as MedLine, PubMed, Wiley Online Library, Web of Science, Oxford University Press, and SAGE Premier. The analyzed period comprised 10 years (from 1996 to 2016). The search for publications was conducted using the following keywords: "cytokine," "pharmacogenetics," "single nucleotide polymorphisms" (SNPs) and "tumor."

\section{Results and Discussion}

Localization of the analyzed cytokine genes and their receptors is presented in Table 1. Summarized data on the association between SNP cytokine genes and the risk of cancer development are presented in Table 2.

Contemporary research shows that cytokines might exert influence upon inter-individual differences in the oncological pain syndrome by hosting different SNP interleukin genes. Persistent neuropathic pain is also associated with depressed mood and deterioration in oncological patients' quality of life. ${ }^{(19)}$ At the present time, studies on SNPs associations in cytokine-coding genes are few. ${ }^{(20)}$ Thus, the following SNPs of the TNF-A gene, which code TNF- $\alpha$, were found to be associated with the risk of cancer development: $1031 \mathrm{~T}>\mathrm{C}$, $863 \mathrm{C}>\mathrm{A}, 857 \mathrm{C}>\mathrm{A}, 851 \mathrm{C}>\mathrm{T}, 419 G>C, 376 G>A, 308 G>A$,
$238 G>A, 162 G>A$ и $49 G>A .^{(21-23)}$ These SNPs increase the risk of cancer development due to a higher level of TNF- $\alpha .{ }^{(24)}$ Currently, SNP $308 G>A$ (rs1800629) of the TNF- $\alpha$ gene is known to predetermine a higher pain syndrome intensity and a lower response to opioids in lung cancer patients, ${ }^{(9,25)}$ being associated with the syndrome of cancer cachexia and fatigue. The CC genotype ( $837 T>C$, rs5275) of the TNF- $\alpha$ gene carriers with lung cancer have a lower risk of severe pain development as compared to carriers of SNP $308 G>A$ (rs1800629) and $50 C>T$ (rs8904) of the NFKBIA-EX6 gene. Moreover, a protective genotype carrier state reduces the risk of severe pain development by $38 \%$. Therefore, investigations into the role of inflammatory gene polymorphism in modulating pain severity is critical in oncopharmacology. ${ }^{(26)}$

Table 1.

Chromosome localization of cytokine genes and their receptors ${ }^{(31,12,42,43)}$

\begin{tabular}{|c|c|}
\hline Genes & Localization \\
\hline \multicolumn{2}{|c|}{ Genes of cytokines } \\
\hline IL-1L & $2 q 13$ \\
\hline IL-1B & $2 q 13-21$ \\
\hline$\Phi H O-\alpha$ & $6 \mathrm{p} 23-\mathrm{q} 12$ \\
\hline IL-10 & $1 \mathrm{q} 31-\mathrm{q} 32$ \\
\hline IL-6 & $7 \mathrm{p} 15.3$ \\
\hline IL-4 & $5 q 23-31$ \\
\hline IFNg & $12 \mathrm{q} 24.1$ \\
\hline IL-18 & 11q22.2_q22.3 \\
\hline \multicolumn{2}{|c|}{ Genes of cytokine receptors } \\
\hline IFNgR1 & $6 \mathrm{p} 23-24$ \\
\hline IFNgR2 & $21 \mathrm{q} 22.1$ \\
\hline IL-6RB & 17 \\
\hline IL-4RA & $16 \mathrm{p} 12.1-11.2$ \\
\hline IL-10RA & $11 \mathrm{q} 23$ \\
\hline $\begin{array}{l}\text { IL-8RA } \\
\text { IL-8RB }\end{array}$ & $2 q 35$ \\
\hline \multicolumn{2}{|c|}{ Genes of cytokine receptor antagonist } \\
\hline IL-1RN & $2 q 13$ \\
\hline
\end{tabular}

Polymorphism of immune response genes (PTGS2, $T N F-A, N F K B I A, I L 6, I L 8)$ is associated with the degree of cancer pain intensity in lung cancer patients. ${ }^{(27)}$ In particular, SNPs rs5277 and rs1799964 of genes LTA and PTGS2 respectively are associated with pain syndrome severity. ${ }^{(26)}$ Polymorphism of the $I L 1 \beta$ gene also predetermines differences in pain perception and changes in morphine consumption during the postoperative period, ${ }^{(10)}$ and in the development of depression ${ }^{(28)}$ and fatigue. ${ }^{(10,28)}$ An increase in the expression of the $I L 1 \beta$ gene causes peripheral hyperalgesia, and vice versa: administration of the IL-1 receptor antagonist leads to suppression of the nociceptive reaction. ${ }^{(5,28,29)}$ SNPs of the following genes are reported to be associated with the burden of pain and with the development of depression and fatigue in patients with lung malignancy NOS3 (1474 T>A, rs1800783), IL1B (allele 31C, rs1143627), TNFR2 (Met196Arg, rs1061622), PTGS2 (837T>C, rs5275), IL10RB 
(Lys47Glu, rs2834167) ${ }^{(30)}$ against the background of existing non-genetic factors (the patient's sex, the stage of cancer). ${ }^{(31,32)}$ SNP $174 G>C$ (rs1800795) of the promoter of the $I L-6$ gene is associated with alterations in the serum level of the cognominal cytokine IL-6. Homozygous carriers of the GG genotype have a higher level of IL-6 expression in comparison with homozygous carriers of the $\mathrm{CC}$ genotype. The majority of African Americans (83.6\%) and Latin Americans (70.5\%) have the homozygous GG genotype, and Europeans have the heterozygous GC genotype. Cancer patients with the $\mathrm{G}$ allele (genotypes $\mathrm{CG}$ and GG) tend to have a shorter life expectancy than patients with the CC genotype. Additionally, SNP $174 G>C$ of the IL-6 gene is associated with pain syndrome severity in patients with nonsmall-cell lung cancer and with daily dosage of morphine (the CC genotype patients require higher doses of morphine in comparison with the CG or GG genotype patients). ${ }^{(33)}$ The homozygous GG genotype patients tend to have lower survivability in cases of sepsis, colorectal adenoma and stomach cancer. ${ }^{(34)}$ Moreover, SNPs of IL6 (rs2069845), IL13 (rs1295686) and TNF-A genes (rs18800610) are reported to be associated with pain, fatigue, sleep disturbance and depression in patients with breast cancer. ${ }^{(19,35)}$

The results of the current studies show the role of $I L-1$ and $I L-8$ in the variability of pain response, the consumption of postoperative morphine, and the development of depression and fatigue in lung cancer patients ${ }^{(20)}$ as well as associations of severe pain with polymorphisms of genes ILIB (rs1143627), ${ }^{(36)}$ IL8 (rs4073), ${ }^{(37)}$ and TNF-A (rs1800629). ${ }^{(20)}$ Research suggests that there are associations between polymorphisms of genes IL1RI (rs2110726) and IL13 (rs1295686) and postoperative pain control for breast cancer patients, and that patients with breast cancer who are carriers of the $\mathrm{C}$ allele in the SNP-marker rs11674595 of the IL1R2 gene, have the risk of developing severe, persisting pain syndrome in the mammary glands. ${ }^{(38,39)}$

Associative dependencies reported in the current studies determine the relevance of investigations into the role of these genes in the genesis of chronic pain syndrome in oncopharmacology. Moreover, genetic polymorphism is described as a possible prognostic marker for the development of adverse reactions; ${ }^{(40)}$ in particular, SNP rs1799964 of the $T N F-A$ gene is a prognostic factor for the development of oral mucositis against the background of chemotherapy in esophageal cancer patients. ${ }^{(41)}$

\section{Conclusion}

The presented literature review attests to a possible influence exerted by the genetic polymorphism of interleukins on the severity and control of cancer-origin chronic pain (nociceptive, neuropathic). The association between interleukin genes polymorphism and chronic pain syndrome control, as well as the pattern of disease progression, is of prognostic value and determines the interest in exploration of targeted influence on the main targets in nociceptive processing: cytokines and their receptors. Individual differences of severe pain, cancer-related weakness, depression, and neurotoxicity of opioids in oncological patients give rise to clinical interest in developing a patient-specific approach to analgesics and accompanying therapy aimed at maintaining quality of life in patients with malignant tumors.

Table 2.

Associations between genetic polymorphism of interleukins and the risk of cancer development

\begin{tabular}{|c|c|c|}
\hline IL & SNPs & Functional role \\
\hline \multirow{7}{*}{ TNF- $\alpha$} & & Protective effect over T-cell lymphoma ${ }^{(44)}$ \\
\hline & $\begin{array}{l}308 \mathrm{G}>\mathrm{A} \\
(\mathrm{rs} 1800629)\end{array}$ & $\begin{array}{l}\text { Lack of association between polymorphism } \\
\text { and the risk of hepatocellular carcinoma } \\
\text { development in people of the Asian race }{ }^{(25)}\end{array}$ \\
\hline & & $\begin{array}{l}\text { The risk of hepatocellular carcinoma } \\
\text { development in the population of China }{ }^{(45)}\end{array}$ \\
\hline & & $\begin{array}{l}\text { The risk of esophageal squamous cell cancer } \\
\text { and esophageal acinic cell carcinoma }(21)\end{array}$ \\
\hline & & $\begin{array}{l}\text { Homozygous (AA) and heterozygous (AG) } \\
\text { subjects have a high risk of colorectal cancer } \\
\text { development in the Mexican population }{ }^{(46)}\end{array}$ \\
\hline & & The risk of oral cavity cancer ${ }^{(22)}$ \\
\hline & & $\begin{array}{l}\text { The risk of esophageal cancer in the } \\
\text { Chinese population } \\
\end{array}$ \\
\hline \multirow{5}{*}{$\mathrm{TNF}-\alpha$} & $\begin{array}{l}308 \mathrm{G}>\mathrm{A} \\
(\mathrm{rs} 180062\end{array}$ & \\
\hline & $\begin{array}{l}857 \mathrm{C}>\mathrm{T} \\
(\mathrm{r} 1799724)\end{array}$ & \\
\hline & $\begin{array}{l}863 \mathrm{C}>\mathrm{A} \\
(\mathrm{rs} 1800630)\end{array}$ & The risk of oral cavity cancer ${ }^{(21)}$ \\
\hline & $\begin{array}{l}1031 \mathrm{~T}>\mathrm{C} \\
(\mathrm{rs} 1799964)\end{array}$ & \\
\hline & $252 \mathrm{~A}>\mathrm{G}$ & \\
\hline TNF- $\alpha$ & $\begin{array}{l}\text { ERCC1- } \\
8092 \\
\end{array}$ & $\begin{array}{l}\text { The risk of hepatocellular cancer } \\
\text { development in the Chinese population }{ }^{(45)}\end{array}$ \\
\hline \multirow{6}{*}{ IL10 } & $1082 \mathrm{GG}$ & $\begin{array}{l}\text { The protective effect in relation to T-cell } \\
\text { lymphoma }{ }^{(44)}\end{array}$ \\
\hline & (rs1800896) & The risk of stomach cancer ${ }^{(27)}$ \\
\hline & $819 \mathrm{C}>\mathrm{T}$ & $\begin{array}{l}\text { The risk of urologic cancer for the Asian } \\
\text { population }{ }^{(47)}\end{array}$ \\
\hline & $592 \mathrm{C}>\mathrm{A}$ & $\begin{array}{l}\text { The risk of colorectal and urologic cancer in } \\
\text { the population of Eastern Asia }{ }^{(47,48,49)}\end{array}$ \\
\hline & $\begin{array}{l}1082 \mathrm{~A}>\mathrm{G} \\
(\mathrm{rs} 1800896)\end{array}$ & $\begin{array}{l}\text { No association with the risk of non-small } \\
\text { cell lung cancer }(24,26)\end{array}$ \\
\hline & $592 \mathrm{C}>\mathrm{A}$ & \\
\hline \multirow[t]{2}{*}{ IL18 } & \multirow{2}{*}{$\begin{array}{l}607 C \\
\text { (rs1946518) } \\
251 \mathrm{~A}>\mathrm{T} \\
(\mathrm{rs} 4073)\end{array}$} & $\begin{array}{l}\text { The risk of non-small cell lung cancer in the } \\
\text { Chinese population }{ }^{(32)}\end{array}$ \\
\hline & & The risk of pancreatic cancer ${ }^{(50)}$ \\
\hline IL4 & $\begin{array}{l}590 \mathrm{C}>\mathrm{T} \\
(\mathrm{rs} 2243250)\end{array}$ & The risk of prostate cancer ${ }^{(47)}$ \\
\hline IL-4R & $\begin{array}{l}\text { rs } 2243228 \\
\text { rs } 2227284 \\
\text { rs2070874 } \\
\end{array}$ & $\begin{array}{l}\text { The risk of pancreatic cancer and cervical } \\
\text { cancer }^{(51)}\end{array}$ \\
\hline IL6 & $\begin{array}{l}174 \mathrm{G}>\mathrm{C} \\
(\mathrm{rs} 1800795)\end{array}$ & $\begin{array}{l}\text { Decrease in survivability of homozygous } \\
\text { GG genotype patients with colorectal tumor } \\
\text { and stomach cancer }{ }^{(52)}\end{array}$ \\
\hline $\begin{array}{l}\text { IL- } \\
1 \mathrm{RN}\end{array}$ & $\begin{array}{l}2018 \mathrm{~T}>\mathrm{C} \\
(\mathrm{rs} 419598)\end{array}$ & The risk of colorectal cancer ${ }^{(46)}$ \\
\hline IL-10 & $\begin{array}{l}\text { CTLA4 / } \\
\text { CT60-AA } \\
\text { CTLA4 / } \\
\text { A49G-AA }\end{array}$ & The risk of renal cell carcinoma ${ }^{(49)}$ \\
\hline
\end{tabular}




\section{Competing interests} interests.

The authors declare that they have no competing

\section{References}

1. Mikaelyan MF, Adzhienko VL. [Conceptions and problems of chronic pain syndrome treatment at the present stage]. Lekarstvennii Vestnik. 2016;2(62): 28-30. [Article in Russian].

2. Yakhno NN, Kukushkin ML, editors. Pain (practical guide for physicians). Moscow: Izdatel'stvo RAMN; 2012. 512 pp. [in Russian].

3. Balashova TV, Andreeva NA, Mnatsakyan LA, Kotelnikova AG, Dolgunov AM. [Present-day ideas on pathogenesis of pain]. Pacific Medical Journal. 2012;3:13-16. [Article in Russian].

4. Wang XB, Li YS, Li J, Han Y, Liu ZD. Interleukin-8 $-251 \mathrm{~A} / \mathrm{T}$ gene polymorphism and lung cancer susceptibility: a meta-analysis. J Cell Mol Med. 2015;19(6):1218-22. doi: $10.1111 /$ jcmm. 12466

5. Schmidt BL, Hamamoto D T, Simone D A, Wilcox GL. Mechanisms of cancer pain. Mol Interv. 2010;10(3):164-78. doi: $10.1124 / \mathrm{mi}$.10.3.7.

6. Yoneda T, Hata K, Nakanishi M, Nagae M, Nagayama T, Wakabayashi $\mathrm{H}$, et al. Involvement of acidic microenvironment in the pathophysiology of cancer-associated bone pain. Bone. 2011;48(1):100-5. doi: 10.1016/j.bone.2010.07.009.

7. Grivennikov SI, Greten FR, Karin M. Immunity, inflammation, and cancer. Cell. 2010;140(6):883-99. doi: 10.1016/j.cell.2010.01.025.

8. Matveeva LV, Mosina LM. [The role of interleukin-1 and associated cytokines in gastric carcinogenesis]. Vestn Ross Akad Med Nauk. 2012;67(11):59-65. doi:10.15690/vramn. v67i11.473. [Article in Russian].

9. Branford R, Droney J, Ross JR. Opioid genetics: the key to personalized pain control? Clin Genet. 2012; 82(4):301-10. doi: 10.1111/j.1399-0004.2012.01923.x

10. Neeb L, Hellen P, Boehnke C, Hoffmann J, Schuh-Hofer S, Dirnagl U, Reuter U. IL-1 beta stimulates COX-2 dependent $\mathrm{PGE}_{2}$ synthesis and CGRP release in rat trigeminal ganglia cells. PLoS One. 2011;6(3):e17360. doi: 10.1371/journal. pone. 0017360 .

11. Hirata H, Tetsumoto S, Kijima T, Kida H, Kumagai T, Takahashi R, et al. Favorable responses to tocilizumab in two patients with cancer - related cachexia. J Pain Symptom Manage. 2013;46(2):e9-e13. doi: 10.1016/j. jpainsymman.2013.01.009

12. Wang XM, Lehky TJ, Brell JM, Dorsey SG. Discovering cytokines as targets for chemotherapy-induced painful peripheral neuropathy. Cytokine. 2012;59(1):3-9. doi: 10.1016/j.cyto.2012.03.027.

13. Guo G, Gao F. CXCR3: latest evidence for the involvement of chemokine signaling in bone cancer pain. Exp Neurol. 2015;265:176-9.doi:10.1016/j.expneurol.2015.02.003.

14. Vendrell I, Macedo I, Alho M, Dionísio MR, Costa L. Treatment of cancer pain by targeting cytokines. Mediators Inflamm. 2015; 2015:984570. doi: 10.1155/2015/984570.

15. JaggiAS, SinghN.Mechanismsincancer-chemotherapeutic drugs-induced peripheral neuropathy. Toxicology. 2012;291(13):1-9. doi: 10.1016/j.tox.2011.10.019.
16. Saijo Y, Tanaka M, Miki M, Usui K, Suzuki T, Maemondo $\mathrm{M}$, et al. Proinflammatory cytokine IL-1 beta promotes tumor growth of Lewis lung carcinoma by induction of angiogenic factors: in vivo analysis of tumor-stromal interaction. J Immunol. 2002;169(1):469-75.

17. Kiguchi N, Kobayashi Y, Kishioka S. Chemokines and cytokines in neuroinflammation leading to neuropathic pain. Curr Opin Pharmacol. 2012;12(1):55-61. doi: 10.1016/j. coph.2011.10.007.

18. Guan XH, Fu QC, Shi D, Bu HL, Song ZP, Xiong BR, et al. Activation of spinal chemokine receptor CXCR3 mediates bone cancer pain through an Akt-ERK crosstalk pathway in rats. Exp Neurol. 2015; 263:39-49. doi: 10.1016/j. expneurol.2014.09.019.

19. Doong SH, Dhruva A, Dunn LB, West C, Paul SM, Cooper BA, et al. Associations between cytokine genes and a symptom cluster of pain, fatigue, sleep disturbance, and depression in patients prior to breast cancer surgery. Biol Res Nurs. 2015;17(3):237-47. doi: 10.1177/1099800414550394.

20. Reyes-Gibby CC, Shete S, Yennurajalingam S, Frazier M, Bruera E, Kurzrock R, et al. Genetic and nongenetic covariates of pain severity in patients with adenocarcinoma of the pancreas: assessing the influence of cytokine genes. J Pain Symptom Manage. 2009;38(6):894-902. doi: 10.1016/j. jpainsymman.2009.04.019

21. Luo M, Yang Y, Luo D, Liu L, Zhang Y, Xiao F, et al.. Tumor necrosis factor-alpha promoter polymorphism $308 \mathrm{G} / \mathrm{A}$ is not significantly associated with esophageal cancer risk: a meta-analysis. Oncotarget. 2016;7(48):79901-79913. doi: 10.18632/oncotarget.13093.

22. Bandil K, Singhal P, Sharma U, Hussain S, Basu S, Parashari A, et al. Impacts of TNF-LTA SNPs/haplotypes and lifestyle factors on oral carcinoma in an Indian population. Mol Diagn Ther. 2016;20(5):469-80. doi: 10.1007/s40291016-0215-2.

23. Zhao H, Zhang HW, Zhang T, Gu XM. Retraction RETRACTION of "Tumor necrosis factor alpha gene -308G $>$ A polymorphism association with the risk of esophageal cancer in a Han Chinese population" by H.Zhao, H.W. Zhang, T.Zhang and X.M. Gu - Genet. Mol. Res. 15(2):gmr.15025866 DOI: http://dx.doi.org/10.4238/gmr.15025866. Genet Mol Res. 2016; 15(4). doi: 10.4238/gmr.150458661.

24. Reyes-Gibby CC, Spitz MR, Yennurajalingam S, Swartz $\mathrm{M}, \mathrm{Gu}$ J, Wu X, et al. Role of inflammation gene polymorphisms on pain severity in lung cancer patients. Cancer Epidemiol Biomarkers Prev. 2009;18(10):2636-42. doi: 10.1158/10559965.EPI-09-0426

25. Sun Q, Guo X, Wang Q, Zhao F. The association of TNF308 (G/A) gene polymorphisms and hepatocellular carcinoma risk: a meta-analysis. Chin J Cancer Res. 2016;28(5):536-542. 26. Rausch SM, Gonzalez BD, Clark MM, Patten C, Felten S, Liu H, et al. SNPs in PTGS2 and LTA predict pain and quality of life in long term lung cancer survivors. Lung Cancer. 2012; 77(1):217-23. doi: 10.1016/j.lungcan.2012.02.017.

27. Wang Z, Liu Y, Yang L, Yin S, Zang R, Yang G. The polymorphism interleukin-8 $-251 \mathrm{~A} / \mathrm{T}$ is associated with a significantly increased risk of cancers from a meta-analysis. Tumour Biol. 2014;35(7):7115-23. doi: 10.1007/s13277-014$1881-5$.

28. Baune BT, Dannlowski U, Domschke K, Janssen DG, Jordan MA, Ohrmann P, etal. The interleukin 1 beta (IL1B) gene is associated with failure to achieve remission and impaired emotion processing in major depression. Biol Psychiatry. 
2010;67(6):543-9. doi: 10.1016/j.biopsych.2009.11.004 29. Reyes-Gibby CC, Spitz M, Wu X, Merriman K, Etzel $\mathrm{C}$, Bruera E, et al. Cytokine genes and pain severity in lung cancer: exploring the influence of TNF-alpha-308 G/A IL6174G/C and IL8-251T/A. Cancer Epidemiol Biomarkers Prev. 2007;16(12):2745-2751. doi:10.1158/1055-9965.epi-07-0651 30. Reyes-Gibby CC, Spitz MR,Yennurajalingam S, Swartz $\mathrm{M}, \mathrm{Gu} \mathrm{J}, \mathrm{Wu}$ X, et al. Role of inflammation gene polymorphisms on pain severity in lung cancer patients. Cancer Epidemiol Biomarkers Prev. 2009;18(10):2636-42. doi: 10.1158/10559965.EPI-09-0426.

31. Müerköster S, Wegehenkel K, Arlt A, Witt M, Sipos $\mathrm{B}$, Kruse ML, et al. Tumor stroma interactions induce chemoresistance in pancreatic ductal carcinoma cells involving increased secretion and paracrine effects of nitric oxide and interleukin-1beta. Cancer Res. 2004;64(4):1331-7. 32. Gan WY, Li HM, Zhang YG, Li CM, Wang Y. Association between IL18-607C/A and $-137 \mathrm{G} / \mathrm{C}$ polymorphisms and susceptibility to non-small cell lung cancer in a Chinese population. Genet Mol Res. 2016;15(4). doi: 10.4238/ gmr15048822.

33. Zhao K, Xu J, Tian H. RETRACTION of "Correlation analysis between an IL-6 genetic polymorphism and non-small cell lung cancer prognosis", by Zhao K, Xu J, Tian H published in Genetics and Molecular Research 15 (1):15017021 (2016) DOI: 10.4238/gmr.15017021. Genet Mol Res. 2016; 15(4). doi: $10.4238 / g m r .15017021$.

34. Quesada JR, Talpaz M, Rios A, Kurzrock R, Gutterman JU. Clinical toxicity of interferons in cancer patients: a review. J Clin Oncol. 2015;4(20):234-43. doi:10.1200/ JCO.1986.4.2.234

35. Von Ah DM, Kang DH, Carpenter JS. Predictors of cancerrelated fatigue in women with breast cancer before, during, and after adjuvant therapy. Cancer Nurs. 2008;31(2):134-44. doi: 10.1097/01.NCC.0000305704.84164.54.

36. Xu J, Yin Z, Cao S, Gao W, Liu L, Yin Y, et al. Systematic review and meta-analysis on the association between IL-1 $\beta$ polymorphisms and cancer risk. PLoS One. 2013;8(5):e63654. doi: 10.1371/journal.pone.0063654.

37. Bastami S, Norling C, Trinks C, Holmlund B, Walz TM, Ahlner J, Uppugunduri S. Inhibitory effect of opiates on LPS mediated release of TNF and IL-8. Acta Oncol. 2013;52(5): 1022-33. http://dx.doi.org/10.3109/0284186X.2012.737932

38. Dahl AA, Nesvold IL, Reinertsen KV, Fossa SD. Arm/ shoulder problems and insomnia symptoms in breast cancer survivors: cross-sectional, controlled and longitudinal observations. Sleep Med. 2011;12(6):584-90. doi: 10.1016/j. sleep.2011.01.011.

39. Mc Cann B, Miaskowski C, Koetters T, Baggott C, West C, Levine JD, et al. Associations between pro- and anti-inflammatory cytokine genes and breast pain in women prior to breast cancer surgery. J Pain. 2012;13(5):425-37. doi:10.1016/j.jpain.2011.02.358.

40. Barratt DT, Klepstad P, Dale O, Kaasa S, Somogyi AA. Innate immune signalling genetics of pain, cognitive dysfunction and sickness symptoms in cancer pain patients treated with transdermal fentanyl. PLoS One. 2015; 10(9): 1-13. doi:10.1371/journal.pone.0137179

41. Sakamoto K, Takeda S, Kanekiyo S, Nishiyama M, Kitahara M, Ueno T, et al.. Association of tumor necrosis factor- $\boldsymbol{\alpha}$ polymorphism with chemotherapy-induced oral mucositis in patients with esophageal cancer. Mol Clin Oncol. 2017;6(1):125-129. doi: 10.3892/mco.2016.1081.

42. Liu X, Wang Z, Yu J, Lei G, Wang S. Three polymorphisms in interleukin-1beta gene and risk for breast cancer: a metaanalysis. Breast Cancer Res Treat. 2010;124(3):821-5. doi: 10.1007/s10549-010-0910-3.

43. Ransohoff RM. Chemokines and chemokine receptors: standing at the crossroads of immunobiology and neurobiology. Immunity. 2009;31(5):711-21. doi: 10.1016/j. immuni.2009.09.010.

44. Nedoszytko B, Olszewska B, Roszkiewicz J, Glen $\mathrm{J}$, Zabłotna $\mathrm{M}$, Ługowska-Umer $\mathrm{H}$, et al. The role of polymorphism of interleukin-2, $-10,-13$ and TNF- $\boldsymbol{\alpha}$ genes in cutaneous T-cell lymphoma pathogenesis. Postepy Dermatol Alergol. 2016;33(6):429-434. doi: 10.5114/ada.2016.63881.

45. Li Y, Ou C, Shu H, Zhao H, Zhu B. The ERCC1-4533/8092, TNF- $\alpha$ 238/308 polymorphisms and the risk of hepatocellular carcinoma in Guangxi Zhuang populations of China: Casecontrol study. Medicine (Baltimore). 2016;95(44):e5217.

46. Gutiérrez-Hurtado IA, Puebla-Pérez AM, DelgadoSaucedoJI, Figuera LE, Zúñiga-González GM, GomezMariscal K, et al. Association between TNF- $\alpha-308 \mathrm{G}>\mathrm{A}$ and $-238 \mathrm{G}>\mathrm{A}$ gene polymorphisms and TNF- $\alpha$ serum levels in Mexican colorectal cancer patients. Genet Mol Res. 2016; 15(2). doi: 10.4238/gmr.15028199.

47. Luo Y, Ye Z, LiK, ChenR, Li S, Pang J. Associations between polymorphisms in the IL-4 and IL-4 receptor genes and urinary carcinomas: a meta-analysis. Int J Clin Exp Med. 2015; 8(1):1227-33. eCollection 2015.

48. Burada F, Dumitrescu T, Nicoli R, Ciurea ME, Angelescu C, Mixich F, Ioana M. IL-1RN $+2018 \mathrm{~T}>\mathrm{C}$ polymorphism is correlated with colorectal cancer. Mol Biol Rep. 2013;40(4):2851-7. doi: 10.1007/s11033-012-2300-x.

49. Sáenz López P, Vázquez Alonso F, Romero JM, Carretero R, Tallada Buñuel M, Ruiz Cabello F, Cózar Olmo JM. [Polymorphisms in inflammatory response genes in metastatic renal cance]r. Actas Urol Esp. 2009;33(5):474-81. [Article in Spanish]

50. Bapat AA, Hostetter G, Von Hoff DD, Han H. Perineural invasion and associated pain in pancreatic cancer. Nat Rev Cancer. 2011;11(10):695-707. doi: 10.1038/nrc3131.

51. Reyes-Gibby CC, Wang J, Spitz M, Wu X, Yennurajalingam S, Shete S. Genetic variations in Interleukin-8 and Interleukin-10 are associated with pain, depressed mood, and fatigue in lung cancer patients. J Pain Symptom Manage. 2013;46(2):161-72. doi: 10.1016/j.jpainsymman.2012.07.019. 52. Ando K, Takahashi F, Motojima S, Nakashima K, Kaneko N, Hoshi K, Takahashi K. Possible role for tocilizumab, an anti-interleukin-6 receptor antibody, in treating cancer cachexia. J Clin Oncol. 2013;31(6):e69-72.doi: 10.1200/ JCO.2012.44.2020 